\title{
The management of time and waiting by unaccompanied asylum-seeking girls in Finland
}

\begin{abstract}
This paper considers how asylum seeking girls in residential care in Finland construct their everyday lives while waiting for asylum outcomes. These girls, from various African countries, are shown to experience waiting as both debilitating and productive. First, our findings confirm the established picture of asylum seeking young people being in limbo, unable to influence the resolution of their claims. Second, we explore more hopeful ways in which they wait. We emphasise the complex responses and relationships they build in waiting times with each other and their carers. We suggest that waiting is not just 'dead' time, but is also lively in periods of uncertainty.
\end{abstract}

\section{Keywords}

Unaccompanied girls, asylum seekers, time, waiting, Finland.

\section{Introduction}

Everything is good, life is good. You get what you need. It's a nice place to wait, and that is what we all do...

In this observation by a Somali girl in Finland, a window is open to particular experiences of waiting. After a long struggle to arrive at a safe place, she is grateful for a period where life is good. Her needs are met, she says, without specifying what these are or how they are met. She finds the place pleasant, perhaps comfortable. And here, along with other asylum seeking young people, she waits to see what will become of her, and who she will become. She begins to endure again, not so much the risks of the past, but the unknowns of a future. It is as if she is in a corridor before entering the living room of the next episodes of her life. In her 
words, she evokes aspects of the elegant observation by Schweizer (2008: 2) that to wait is to have time without wanting it. Waiting, in that respect, is portrayed as a break in the melody of living.

In contexts of asylum seeking, waiting is often presented as unremittingly bleak - an arid stretch of time, where the clock ticks, but no movement happens. Particular when such time is measured only in reference to future outcome, dread and hope are noted to combine (author citation withheld for peer review, Allsopp et al. 2015; Rotter 2016, Conlon 2011), creating vortexes of uncertainty. Here, a 'yes' attached to an outcome of remaining in the country of asylum, and a 'no' that foreshadows further forced migrations from that country towards potential dangers elsewhere, leads many asylum seeking children to surmise that they lead 'half-lives' (Brighter Futures 2013: 15), unable to find ground in which to root, and grow up. In such 'somewhere, nowhere' circumstances, dreams and nightmares co-exist. Corrosion of the self happens, and composition of the self is neglected. Time is thick or fast, depending on what is happening, and how quickly things move, or are experienced as moving. And the tensions between different types of movements - either growing up safely or moving out towards more danger - are acutely present. For example, as noted by one of us elsewhere:

Long periods of doing nothing at all are punctuated with short bursts of asylum application activities, within which time is elongated and compacted according to the tempo and pace of the asylum claim. Moments, hours, days, weeks and years can be spent consuming time, and watching time. Each portion of time is context dependent, so that moments are sometimes slow, and years go by very speedily as adulthood approaches. In some respects, this is an experience of purgatory, and waiting in limbo, where the road to a secure future is full of diversions and traffic lights, as they become part of a queue of applicants looking at a horizon (author citation withheld for peer review) 
However, the external ticking of the clock leading to a clear future is only one facet of their experience of waiting time, and we suggest in this paper that not everything is bleak for children, as the above quote appears to claim. Our focus is to examine in detail the relationships that asylum seeking girls develop with themselves and others in dealing with times of stillness and movement while waiting for decisions to reach them, as they reach out towards connections that will sustain them - connections that belong to the past, to the networks in the present, and to future anticipations. Our intention is to draw out the details of everyday living in residential care, where much of the re-building of the rhythms and patterns of life occurs.

The lives of unaccompanied asylum seekers and refugees have been explored extensively in recent years, (i.e. the Refugee Studies Virtual Issue: Unaccompanied Minors, 2016), although, more research is needed (Koser 2016: 1). For example, Wade et al (2013) have focussed on foster care, Vervliet et al (2015a) on unaccompanied young people's aspirations and wishes for the future, and Allsop et al (2015) on the challenges faced by them in 'becoming adult' while being subject to immigration controls. The Finnish context, on which this study is based, has also gained scholarly attention, especially since the rapid increase in the numbers of asylum seeking children in 2015 (Kuusisto-Arponen 2016; author citation withheld for peer review). Yet, little attention has been directed to the ways in which waiting unfolds in their everyday lives, and how they manage their time. Moreover, refugee research mainly present the voices of male asylum seekers as a norm and leaves the gendered aspects of forced migration untouched, even though calls to 'mainstream' gender have been made in research, policy and practice regarding refugees for decades (Hyndman 2010; United Nations High Commissioner for Refugees [UNHCR] 2016). Feminist perspectives in refugee studies 
(Conlon 2011; Fiddian-Qasmiyeh 2016; Hyndman 2010) call for an elaborate analysis of the forces that shape gender and other politics of forced migration. In this paper we delineate how these forces play out in relation to gender, age and asylum status. We consider the multiple nature of waiting: how it is encountered and woven into the everyday lives of the girls of this study, and how apparently passive waiting can be interpreted as acts of resisting, managing or even benefitting from the situation.

This paper is structured as follow. Initially we discuss the concept of waiting, and associated conceptual aspects of time and movement. We consider how 'outside' linear time, and 'inside' experienced time interact. Secondly, we briefly outline the methodological approaches used in a study with unaccompanied asylum-seeking girls in Finland. Thirdly, through organising the girls' responses in interviews and group discussions, we focus on specific findings in relation to 'waiting time'. We conclude by considering the implications of our findings for asylum seeking young people who wait. We propose that there is no single story of suffering that quite captures the multiplicity of responses that young people make in limbo. We suggest that paying attention to the ways in which the girls in Finland insist on finding ways of living ordinary lives helps us to understand the ways that asylum seeking young people assert their rights to be alive and to live on.

\section{Key concepts and issues}

When waiting, time is endured rather than traversed (Klein 2006). In waiting time, the person waiting can sense that they are excluded from a community of productive citizens. People in charge of their own time can carry on with life con brio, with a rhythm and pace that keeps them moving onward and upward (Levine 1997). For such people living in a world where their own habits of velocity are valuable, doing things on time and being time efficient 
become assets worth pursuing and protecting. Time is not just money, it is also confers power to shape their contexts, and allows them to be valuable and distinctive in their trajectories. They spend time like a commodity. In contrast, waiting time creates an empty and fearful listlessness, akin to experiences of grief. CS Lewis (1978), in observing his own grief notes that:

...grief still feels like fear. Perhaps, more strictly, like suspense. Or like waiting; just hanging about waiting for something to happen. It gives life a permanently provisional feeling... Up till this I always had too little time. Now there is nothing but time. Almost pure time, empty successiveness. (Lewis 1978: 38-9)

The presence of absence in this 'empty successiveness' is well documented in the literature on asylum seekers and waiting. Their prolonged waiting can take the form of 'permanent impermanence' - a static state of being which they do not want to inhabit, awaiting a future they cannot reach (Brun 2015: 19). Waiting is inevitable but it comes at a cost. As asylum seekers, people can feel rudderless. Unable to find ground in which to root, unable to live an unrestricted life can result in refugees who wait becoming passive in their longing for the past and consequently, devoid of any sense of being in charge of their future trajectories (Brun 2015). Although experiences of cycles of waiting, escape and arrival are diverse, waiting time is noted as being long and empty.

The spaces in which refugees wait are portrayed as static holding places where everything, time and people, stay still. They are waiting rooms, or as Hyndman and Giles (2011: 362) dramatically put it, human storages in which refugees have 'a right not to die'. The spaces are often geographically distant from the rest of society: camps in the global South or in other 
isolated pockets, to keep those waiting out of sight (Hyndman and Giles 2011). Here, what is common is that although refugees are mostly free to leave, they have no reason and no means to do so (Larruina and Ghorashi 2016: 231). They inhabit 'container spaces [which] are designed to hold the body, where the body is prompted to remain inert in a form of temporary stasis'. (Bissell 2007: 282) This is because they live in a time of 'disruption of life before and after and legal and jurisdictional ambiguity that inhibits access to rights and protections' (Mountz 2011: 381). Thus, refugees are portrayed as being stuck in time and place and consequently passive and dependant on others.

Some scholars have challenged these graphic portrayals within the field of (forced) migration (including Hyndman and Giles 2011 and Mountz 2011). The core of the critique is that the evocation of such images of suffering fails to recognize that waiting is not merely a distinctive spatial and temporal dimension of immobility. Waiting is a dynamic effect of international geopolitics and an indicator of motility - that is, predicted mobility (Conlon 2011). People seeking asylum have made journeys across geographical spaces and across borders to reach the destination country. They know that when the 'yes' or 'no', attached to an asylum decision reaches them, they will make a journey again, either to safety or another destination of forced migration. They wait because of mobility and for mobility. While waiting, everyday life continues to flow through routinized practices and different survival strategies (Brun 2015: 19, 23).

Childhood brings additional layers to waiting. As Qvortrup (2004) suggests, 
It is the fate of children to be waiting. They are waiting to become adults; to mature; to become competent; to get capabilities; to acquire rights; to become useful; to have a say in societal matters; to share resources. (Qvortrup 2004: 267)

But not all waiting is the same. Situational, instrumental waiting is a part of life for everyone, whereas prolonged, open-ended waiting during childhood can do long lasting harm. Sourander (1998: 723), in reference to unaccompanied children, notes that it is distressing and anxiety provoking and thus influences well-being in the present. The ambiguousness of waiting, together with precarious living conditions in which asylum seeking children often wait, positions them into 'no-place' and as being 'no-one', leading to what Vitus (2010: 41) sees as the de-subjectification of children. In addition, as McEvoy-Levy (2014) observes, being 'stuck' in time and place due to asylum status can result in developmental 'stuckness', the inability to make a transition from childhood dependence to adult independence. In all, the cost to children in these circumstances is plentiful, to a point where the melody of living that we refer to turns instead to silence or noise, disrupting the patterns and rhythms of growing up sustainably and safely.

But as we noted, young asylum seekers' waiting is not only bleak, stressful, hopeless and empty. Even though waiting is first and foremost instrumental, directed towards a clear goal, it is not only that. It is also 'socially produced, ... actively encountered, incorporated and resisted amidst everyday spaces' (Conlon 2011: 353). Some studies have begun to show that waiting is active as in one way or another, young asylum seekers start to recover from past experiences by building everyday life worth living. Some do it by creating routines. For example, in Vitus' (2010) work, a young asylum seeker found comfort in observing rabbits being born and developing. Allsop et al (2015) observe that establishing such routines and 
finding a valued role in life can give unaccompanied children a sense of 'ontological security' as an important counterweight to the pervasive sense of living in limbo. In other studies, evidence has emerged of the ways unaccompanied children composed themselves by carefully and persistently taking care of their own responsibilities, such as schoolwork (Kuusisto-Arponen 2016: 107), or building pride and a feeling of worth by doing things they are good at (author citation withheld for peer review), and using silence tactically to claim ownership of their own time while waiting (Chase 2010, author citation withheld for peer review). In the study by Allsopp et al. (2015) engaging in visits to museums, trips to the countryside or participating in youth clubs or religious groups allowed each day to flow in an orderly way and gave young asylum seekers a sense of moving forward during precarious waiting. Uzureau and Senovilla Hernandez (2016), in conducting a project with migrant children accommodated in hotels by social services in a provincial French city, tell the story of a young Congolese boy and his companions. With others, he waited for his status as an 'unaccompanied child' to be determined and to be integrated into a suitable accommodation facility for children in need. They all complained of stale routines, ('Everyday is the same: eating, sleeping, watching TV. There is no school, no training, no education'), and how the absence of navigation points for their lives created anxiety that 'burns the brain' (Ça nous chauffe la tête). Yet from within the lassitude and ennui that they experienced, little shifts of energy and organisation emerged to tip the balance towards some sense of being in charge of their lives. One of them noted 'Waiting involves acting in the meantime. They recommended me to wait without doing anything but I do things because there is no time to lose'. Playing sports, and particularly football, created small and temporary escape velocities to counteract the gravitational pulls of an imposed lethargy. Others fabricated their own provisional spaces for activities - through creating an ad hoc space close to the city railway station where they regularly practiced bodybuilding exercises while pedestrians walked along. Other young 
people anticipated their integration into mainstream school or vocational training and practiced everyday language or maths exercises that they downloaded to their mobile phones at free Wi-Fi spots or at public libraries. The young Congolese boy, as part of a photography project run by the researchers, submitted two photos - one of a park bench, another of a textbook covering a range of academic disciplines. Alongside the textbook were a selfwritten weekly timetable and a library card.

\section{[Insert image 1 here]}

Each day of the week, the boy sat at the park bench, with this textbook, and faithfully followed the curriculum. Through these observations of life coming back within the margins of living, Uzureau and Senovilla Hernandez (2016) observe a certain obstinacy from the young people in the face of having to cope with waiting. They also confirm that the insistence on living does not happen by chance. It requires organisation, exertion and practice to make it happen (author citation withheld for peer review). Within this complex mix of fears, anticipations, and everyday re-constructions of the facsimiles of living, our enquiry took shape. We now describe the context and methods of the enquiry in order to set the frame for our findings.

\section{Context and method}

In what follows, we discuss the experiences of waiting for 12 unaccompanied asylum-seeking girls living in a reception centre in the Northern Finland during 2011-2012. During the data collection, the numbers of unaccompanied asylum-seeking children arriving in Finland were relatively low (150 in 2011; 167 in 2012). The situation changed rapidly in 2015, when 3024 unaccompanied minors, most of them from Afghanistan (1915), Iraq (635), and Somalia 
(253), came to Finland (Finnish Immigration Services 2017). The accounts of the girls, living in half-empty living units with very few peers from their own countries, paint a picture of Finland that has changed as numbers have grown. Living units are now fuller and the demands on Finnish welfare and other services are higher. Yet there is a need to understand how asylum seeking children experience waiting times.

The empirical data was gathered by one of us in two six-month periods as part of a larger study focussed on the meanings given by children to 'child participation' in asylum seeking contexts (author citation withheld for peer review). The research design was a participatory action research (PAR), which is a collective process of inquiry aiming to solve everyday issues and - to a greater or lesser extent - address problems of inequity (more about the methodological choices of this research in (author citation withheld for peer review). By understanding the meaning of child participation from the perspective of unaccompanied girls, this PAR aimed to tackle a practical issue of the lack of activities which would be inviting and meaningful for the girls at the reception centre; to fill some of the "empty successiveness' that comes with waiting. By doing this, the study also aimed to assist different stakeholders to have a detailed and nuanced understanding of the needs of girls, who were in the minority among unaccompanied children in Finland during the time of this study (15\% in 2011-2012), and still are (Finnish Immigration Services 2017). Girls were also a new group of residents in the centre where this study was conducted. Boys were active in hobbies such as football and floorball, whereas the girls found it hard to get involved in such activities, or in fact, any activities with boys. Hesitance to socialise with boys was linked by some of the girls to experiences of gender-based violence. Furthermore, all of the girls came from countries where the interaction between young women and men was quite restricted by tradition and custom (Somalia, Angola and Democratic Republic of Congo). Thus, creating 
activities only for the girls, on their terms, also aimed at creating a gender-sensitive, safe space within the reception centre, Therefore, focussing on girls addressed a practical need as much as a research gap.

PAR was chosen because, as the prefix 'participatory' suggests, it can take many forms depending on what the participants see as relevant. For instance, during the course of the project it became clear that sharing personal information of any kind, however neutral it may appear, can at times be seen as dangerous in the eyes of an asylum seeking child (author citation withheld for peer review, and Doná 2007). In the beginning of the project, the girls guarded their privacy closely. When they started to talk more, they constantly emphasised that they were telling the truth, and checked who would get access to the information they provided. Mistrust, and the feeling of being mistrusted by others, is common among asylumseeking children (Ni Raghallaigh 2014). Being sceptical about research is understandable for those who have no previous experience being researched, and who might not have a full understanding of anonymity or voluntariness of participation. Fieldwork spreading over an extended time helped to create trust between the girls and the researcher, and the child-led, fun elements of the project enabled the girls to not only give their accounts for research, but also provided an opportunity to use their waiting time in ways where their talents and interests were on show, not just their needs. This resonates with the argument by Vervliet et al. (2015b) and Halilovich (2013), that research with refugee children requires more than a good grasp of relevant theories, suitable techniques or following procedural ethical guidelines. Importantly, it requires relational ethics, i.e. the inherently situational, moment to moment decisions in regard the most suitable actions, to ensure the dignity and the safety of the participants. 
All phases of this project were designed to allow the girls to be involved in the planning, conducting and evaluating as much or as little as they wanted, on their own terms. Voluntariness and participatory nature of the project were covered in many interpreted discussions. Research tools were modified to maximise privacy and confidentiality for the girls. For example, some group discussions were not audio recorded, and one of the two groups was not photographed at all. Required institutional ethical approval and consent were attained from the girls and their guardians before starting the study. In all, two groups of unaccompanied asylum-seeking girls (in total 12 girls, aged 8-17) took part. Their countries of origin were African. The reception centre arranged professional interpreters in all available languages for the PAR meetings and interviews. Interpreting sometimes generated some tensions in the meetings. As noted by Westlake and Jones (2017), in situations of low initial trust, rapport needs to be established and sustained in any encounter. Given the central importance of ensuring that the girls could voice their opinions regardless of their limited Finnish proficiency, this was achieved by all participants. In emphasising the 'action' in 'action research' both groups decided to organize a camp with different, child-led activities outside of the reception centre. During the main study periods it became clear that the experience of waiting was pervasive, and in that sense meaningful participation was about how to make the waiting worthwhile and to help the participants fill empty time. For the purpose of this paper, the qualitative data (interpreted individual interviews, group interviews and researcher field notes from observation) were organized and re-analysed, specifically focusing on the experience of waiting.

\section{Cost of waiting}

For all the girls in this study, waiting was first and foremost instrumental. It was directed to a specific, life-changing goal of asylum decision and a promise to start building a life in 
Finland. Waiting for the decision was costly, and the cost was clustered around aspects of stuckness and boredom in the present as well as the unpredictability of the future. These aspects of waiting confirmed the established picture of young people being in limbo during their asylum process.

When you live in a strange country without your parents and when you can't even speak to anybody, it is like you have a door closed here and here (showing to the front and back of her). You can’t go back but you are not yet here.

Limbo refers to the marginalisation, control and stasis of people (Brun 2015). It is a phase in which both people and the sites that they inhabit are neither precisely 'here' nor 'there' (Mountz 2011: 382). People are, like the girl above notes, between closed doors, and the site is a waiting room for real life. For the girls of this study, this is how they said their circumstances often felt, echoing the observations by Hoffmann (1989) of her experiences as a migrant child:

I can't afford to look back, and I can't figure out how to look forward. In both directions, I may see a Medusa, and I already feel the danger of being turned into stone. Betwixt and between, I am stuck and time is stuck within me. Time used to open out, serene, shimmering with promise. If I wanted to hold a moment still, it was because I wanted to expand it, to get its fill. Now time has no dimension, no extension backwards or forwards. I arrest the past, and I hold myself stiffly against the future; I want to stop the flow. As a punishment, I exist in the stasis of a perpetual present, the other side of "living in the present" which is not eternity but a prison. I can't throw a bridge between the present and the past, and therefore I can't make time move. (Hoffman 1989: 116-117) 
Peaceful feelings of being safe in an asylum country were gradually shadowed by an increasing frustration about not being able to go on with own life, and a worry about the unknowns of a future. The girls felt stricken by the power of bureaucratic systems and because of their legal status. It had its own pull on how they felt and on what they could dream of, but also on the way they were treated while waiting. In their world, gravity felt heavier than for people with more ordinary lives:

We shouldn't be moved. If somebody decides, then you go there. You don't know what kind of place it is, you don't know anybody, you don't know anything about it. ...I wasn't asked, I was just given a time. This day you will go, nothing else. ... Nobody told me why or asked me if I wanted to go. I was surprised; I had been told that after the immigration interview I will be moved somewhere, but before the interview I was told I have to go.

For this girl, waiting for the next, unpredictable move influenced her coping with everyday time. She became conscious of the interaction between 'outside' linear time and 'inside' experienced time due to the mismatch between decisions that had an impact on her and her own ability to influence them. Thus, situational, purposeful waiting for the 'yes' was replaced with existential waiting, not even knowing what to wait for (author citation withheld for peer review). This position of not knowing made time tangible; the girl became able to feel time and its implications (cf. Vitus 2010: 33). Bearing the not knowing was challenging for all the girls.

Police tells me that they will find my parents. I don't know, I just wait to hear what they will say. I don't know, I just wait. 
What was even more challenging, as noted by Vitus (2010) and Mountz (2011) was that not only the outcome but also the length of waiting was unknown.

(From field notes) [Name] told me that sometimes, on bad days, they feel like prisoners. What is even worse, the difference is that prisoners know the length of their sentence, unlike these young people.

An array of research studies confirm that a history of managing alone can feel lonely for children, deprived of the scaffolding of care from protective adults (see, for example, Mann 2004; Bean 2006; Sirriyeh 2013; Vervliet 2013). Also, coming from areas of war and crisis, children might have trouble in trusting people they do not know (Ni Raghallaigh 2014). The girls in this study were clear that while adult professionals were not substitutes for family ties, day-to-day practical support from helpers was appreciated. The girls argued that as the practitioners taught them everyday skills, they paved the girls' way for the 'real life' as independent young women. Nevertheless, some of the girls struggled in reaching towards available adults when they needed more than practical support, through a combination of responsibility towards others, and well as a wish to safeguard their own feelings:

It is difficult to talk about this (being sad and missing family), because they (practitioners) also have children. So, it must be hard for them to divide love between us and their own children. So, it is difficult to talk about this.

INT: Do you mean it is difficult to talk about missing your family, or to talk with the practitioners?

Yes. Both. 
Through such exchanges the girls showed that in a context where they belonged to no one, and no one belonged to them, they quietly and carefully carried their sadness while waiting.

Many of the participants confirmed that their housing and living conditions were mostly good. The girls, like the participant quoted at the beginning of this paper, appeared happy with the care they received. They all had access to some form of education and were free to move around, in and outside the living unit. However, what appears as limiting is, to some extent, relative, subjective and contextual. The girls' words of criticism were rare. In placing new experiences alongside old ones, some said that unknown surroundings, and even the intimidating, dark forest around the centre prohibited them from moving outside. Far from the warmth of Africa, having to cope with a long Finnish winter posed another challenge:

(Field notes) The girls told me what they did after school, which they had for two hours a day. They told me they walk along the corridors. I asked if they ever walk outside, on the long nature trails surrounding the centre. They said they couldn't because it was in the middle of winter. They told me that the corridors are long enough to walk in but it gets boring.

The girls confirmed that an unknown future was hard to fill and their creeping existential boredom hard to bear, exactly capturing Schweizer's (2005: 777) observation that a 'time of boredom is empty, it has neither object nor end'. For the girls, it was the blankness in their future that made the boredom hard to handle. When expressing boredom, the girls revealed how they tried to punctuate a sense of borderless waiting time by trying to puzzle out the fit between their past habits and future dreams. For example, some of the girls considered that the way they were treated as unaccompanied minors contradicted their past experiences. They felt they were waiting for adulthood and independence that they had already achieved: 
In our country, if you are a 15-year-old girl, you already have your own life, own room and own things; you are on your own. You are already an adult.

Waiting as time without wanting it, was paced by instances of short-term waiting, such as waiting for a meeting with personal caseworkers, next stages in the asylum-decision, and changes in the living situations. Similar to the ways sporting activity in France helped to soften the edges of harsh living (Uzureau and Senovilla Hernandez 2016), the girls of this study found temporary escapes from their waiting in a form of organized trips outside the centre, celebrations on special days or events with other young people. These activities counteracted the imposed lethargy, bringing some structure to everyday life and making waiting time easier to manage and metabolise.

For example, if we go somewhere... If I start missing my mother and my father, it is better to go somewhere else. Not to be here all the time. It is very boring to always be here. Here I only think about sad things.

Yet sometimes even these little instances of waiting were hard for the girls to bear. Their restlessness and irritation were revealed during the PAR-meetings, where some of them paced back and forth, in and out of the meeting room, sitting down and standing up, impatient to have a turn with the activity of the day, for others to arrive, and for a change of activity. When asked about this sense of impatience, many of the girls played down their own irritabilities, answering that 'all was good', almost embarrassed, perhaps assuming their behaviour would be considered as inappropriate. Over time we observed that in contrast to the standard clockwork movements of running the residential unit, the PAR meetings were set up with an invitation for the girls to own their time and to do with it as they wished. In its 
design, this was a purposeful invitation based on an understanding that the more regimented and tight-knit routines of a residential unit - where compliance to schedule and neatness were culturally valuable - needed a counterpoint where the girls could be less marshalled, and experience a more loose-weave way of behaving and having fun. In itself this contrast between tight-knit and loose-weave was based on a broader understanding of the ways asylum seeking children experience the balances between regulations and freedoms in countries of asylum, where immigration rules heavily trump the lightness of wayward ordinariness. In the context of PAR, the girls' decisions not to participate, or to disagree with activities others suggested, allowed them to create provisional spaces for doing what they wanted: they could control their own time in a way which was encouraged and accepted.

Although waiting was still, frustrating and boring in many ways, it did not stop movement from happening. Time flowed in all directions: During the asylum process, the girls grew older and thought about their future lives as independent adult women. They dreamed about growing up, travelling the world, studying, getting work and starting a family. Annual time passed, giving rhythm for other aspects of life. The girls confirmed that time moved faster during the light and warmth of summer and dragged on during the long and dark winter. Waking up was hard when it was dark outside, just like energy for activities was scarce in the afternoon, when it was dark again. The girls discussed with excitement the melting snow, increasing daylight and nature turning green. Seasons changed and adulthood came nearer when the girls seemed to stay still, between two closed doors. Waiting for the doors to open did not only cause anxiety among the girls, it also created hope. The girls knew waiting would eventually come to an end and even though there was nothing to do to make time go faster, they were hopeful for a positive outcome. The most important outcome, according to all girls was a promise to live permanently in Finland. 


\section{Hope in waiting}

While the girls genuinely asked 'Why change something so temporary' when considering how to make the present situation more bearable, it was clear that they imbued waiting with hope. There was hope in the way the girls re-constructed the rhythms and patterns of everyday life with others who waited. Instead of going solo, they negotiated roles and tasks to build a functional community in a transient group. While doing that, they also sought a rhythm that suited them all, and regained some independence in their lives. The girls wanted to use their skills to be active in their liminal situation, rather than being entrapped. They turned away from boredom by filling some of their time with activities that brought them comfort. They shared music from their countries of origin; they also created a fan club around a young, Finnish pop idol. They reached out towards each other, towards a shared, temporary home, and towards their lives outside of the centre. They said that without hope they would not have bothered. As the girls re-constructed their lives, they challenged the provisional feeling of waiting.

While the girls figured out commonplace habits, customs and rhythms of living they also negotiated between integrating and disintegrating. They reached out towards connections that would sustain them while carrying parts of their childhood worlds of origin into the new situation. For some of the girls, persistent way of maintaining religious rituals and other familiar habits gave comfort during waiting:

I celebrate our own holidays here. Our traditions are respected here (at the reception centre), practitioners even help us.... If we need to go somewhere to pray, they even take us and bring back. I think they respect us. 
At the same time, some of the girls purposefully discarded elements they wanted let go of, or accepted that they could not hold onto them anymore:

I don't need my friends from Somalia. I don't! I have new friends here. ... I have searched online sometimes, to find some friends, but I don't even find them. People use many names, I couldn't find them with the names I know.

While simultaneously negotiating integrating and disintegrating, the girls built complex interdependencies. 'It is nice to see when people move around. It makes me feel not alone,' one girl said, continuing that when she had arrived in the centre, she had nobody who spoke her language. Nevertheless, she had decided to spend her free time in the common room, sitting on the couch, watching people, smiling and saying hei (Hello in Finnish) to everybody. She said that the way other people responded, smiled back at her and noticed her, even without being able to speak to her, made her feel like she existed. Another two girls, who spoke different languages, made felt hearts out of wool for each other. While engaging in the needlework, the girls used the few words they knew in Finnish to communicate. The girls understood each other and laughed together, making an effort to bond. On another occasion, one of the girls argued: 'There are no groups [cliques], we are all one. We are close with everybody, if we understand one another. And if we can tell jokes, then we can be friends'. And even without enough words for jokes, the girls managed to orchestrate activities in which other could join.

\section{[Insert image 2 here]}

The way the girls reached out to each other across language barriers and attempted to create homeliness showed that they actively worked to fill their time and space with solidarity. As 
the girls shared and understood each other's waiting, they also made waiting as smooth as possible.

Here are a lot of people, different people, all the time action. All places with a lot of people you will miss them when you go away.

I speak about us (the young people at the centre) as one group. If we share a language, if some speak their own language, they can speak it but it is not a problem for others.

Some of the girls' anxiety was gradually eased through increasing reciprocal trust towards each other and adults around them. The girls started to believe that their best interest was considered in their care, and the adults were there to help. Trust increased towards the practitioners; also towards the researcher.

(Field notes, PAR meeting after five months with the first group): Now the girls come to sit close to me on the couch. They hold my hand, tell me private things, ask for help. We have certainly came a long way from the time when I tried to reason why they should want to have anything to do with me and this project.

\section{[Insert image 3 here]}

Also, as time passed, the girls' began to embrace stillness rather than activity. After risky and lonely journeys, the possibility of being able to stop and be cared for by others was appreciated. Some of the restless pacing was replaced by times of doing nothing together. The five-month mark, reported in the field note entry above, illustrates a beginning of a phase in which the girls started to welcome the researcher to their temporary home, allowing her to 
join them in their private, everyday life. This was as close as an outsider could get to share, and to understand some of the aspects of waiting the girls experienced. Understanding the girls' waiting required an invitation to wait with them, and eventually to watch as their ordinary lives unfolded.

There was also hope in the way the girls prepared themselves for the future. Like many children with refugee background in Finland (Björklund 2014) and elsewhere (Vervliet et al. 2015), they had ambitions but were fully aware that fulfilling these would take time. Waiting for a viable future was double-edged: frightening in its unpredictability, but nevertheless, exciting. Many noted that they did not know if their biggest dream, reuniting with their families, would ever come true, but they were keen to start their own lives as well as they could. Some were mindful about the other realities of life:

In five years, I will study to become a nurse. Yes, if I don't die before that.

All wanted to go to school and get a job, reflecting the will to reciprocate and become part of the 'nucleus of a functioning society' (author citation withheld for peer review). All wanted to live in Finland, and all who had family, wanted to have family members with them. Although the words of the answers varied, the essence of this ambition was captured by one of them:

I want to study. I want to be somebody.

The girls understood that even after receiving permission to live and study in Finland, fulfilling their dreams of becoming nurses, doctors or teachers would require more waiting. They saw that kind of waiting as being purposeful, no matter how long it took. So they 
planned and pushed to define the steps required to achieve their dreams. For others, there was less intentionality, but a similar sort of hope in looking to a settled life, mixing the old with the new, as in the following encounter.

Researcher: What will you do in five years?

Girl: Turkey... (in Finnish: Turkki)

R: Turkey?

G: No! Tulkki (Finnish for Interpreter)

Interpreter: Yes?

G: Not you! Turku! (a city in Finland).... I will live in Turku. With [names of her brothers and a cousin].

R: Oh, I see. Have you been in Turku?

G: No.

R: Why do you want to live there?

G: It sounds nice!

So by intent or by default, in waiting time they looked outwards towards a future, sometimes clear, and at other times occluded. For the girl in the above encounter, joining the past and the future was a mixed bundle of intentions and confusions, mixed with a little hope that her life, in the end, would work out.

\section{Summary}

Due to the small number of participants, this group cannot be seen as representative of the whole population of unaccompanied girls in Finland. Nor, in our view, are the findings generalizable, given the wide variety of histories and circumstances of unaccompanied children. However by seeking to capture and articulate some ways in which waiting was 
experienced among these girls, we have attempted to highlight important themes that, in our view, are beginning to emerge, and require further exploration. We have shown that the girls' waiting time was embedded in complex networks with other times and spaces, and produced together with others who wait. We have shown how the girls dealt with times of stillness and mobility; how 'outside' linear time, paced with the rhythm of the everyday, interacted with their 'inside' experienced time. We have considered how times of stillness were full of movement, and how that movement took the girls closer to 'real life' after waiting.

In all, the experiences of these asylum-seeking girls show that waiting is a prison, in the familiar sense of being located within a dislocation. And yet it is also a prism through which everyday experiences, talents, and desires are refracted in ways that generate a sense of being alive, alert and assertive in everyday life. The everyday was not just a liminal gap between two phases in living. Rather, it was a long period of real life, with the girls' growing up. In liminal circumstances where the past was occluded and the future uncertain, the girls in this project did not want to merely wait for the 'real life' to start. After having experienced the death of everyday life in their countries of origin and their journeys to Finland, they made attempts each day to be regenerative. (author citation withheld for peer review). Yet their new beginnings were fragile, like plants growing between two blocks of concrete. As they grew up, the girls refused to surrender to boredom. Instead, they insisted on maintaining their energy and liveliness during waiting times, even when it tested their capacities to carry on. It was the girls' way of feeling alive, and living on.

\section{Acknowledgements}

The research was funded by Academy of Finland (SA 304146), Finnish Cultural Foundation, Mannerheim League for Child Welfare and Finnish Multidisciplinary Doctoral Training 
Network on Educational Sciences. The article was written between June 2016 and January 2017.

\section{References}

ALLSOPP, J. CHASE, E. and MITCHELL, M. (2015) 'The Tactics of Time and Status: Young People's Experiences of Building Futures While Subject to Immigration Control in Britain'. Journal of Refugee Studies 28(2): 163-182.

BEAN, T.M. (2006) Assessing the Psychological and Mental Health Care Needs of Unaccompanied Refugee Minors in the Netherlands. Leiden, The Netherlands: Leiden University.

BISSELL, D. (2007) 'Animated Suspension: Waiting for Mobilities'. Mobilities 2(2): 277298.

BJÖRKLUND, K. (2014) Haluun koulutusta, haluun työtä ja elämän Suomessa. Yksintulleiden alaikäisten pakolaisten kotoutuminen Varsinais-Suomessa. Turku, Finland: Institute of Migration.

BRIGHTER FUTURES (2013) The Cost of Waiting. How Waiting in Limbo for Immigration Resolution Affects the Lives of Young Asylum Seekers and Young Migrants in the UK. London, Brighter Futures Report 10/07/2013.

BRUN, C. (2015) 'Active Waiting and Changing Hopes: Toward a Time Perspective on Protracted Displacement’. Social Analysis 59(1): 19-37.

CHASE, E. (2010). 'Agency and Silence: Young People Seeking Asylum Alone in the UK’. British Journal of Social Work, 40(7): 2050-2068.

CONLON, D. (2011) 'Waiting: Feminist Perspectives on the Spacings/Timings of Migrant (Im)mobility’. Gender, Place \& Culture: A Journal of Feminist Geography 18(3): 353-360.

DONÁ, G. (2007) 'The Microphysics of Participation in Refugee Research'. Journal of Refugee Studies 20(2): 210-229.

FIDDIAN-QASMIYEH, E. (2016) 'Gender and Forced Migration'. In Fiddian-Qasmiyeh, E., Loescher, G., Long, K. and Sigona, N. (eds.) The Oxford Handbook of Forced Migration and Refugee Studies. Oxford, UK: Oxford University Press, pp. 395-406.

FINNISH IMMIGRATION SERVICE (2017) Statistics of asylum and refugees. Available at $<$ http://www.migri.fi/about_us/statistics/statistics_on_asylum_and_refugees $>$ (accessed 05/04/2017)

HALILOVICH, H. (2013) 'Ethical approaches in research with refugee and asylum seekers using participatory action research'. In Block, K., Riggs, E. and Haslam, N. (eds.) Values and 
Vulnerabilities. The Ethics of Research with Refugees and Asylum Seekers. Toowong, Australia: Australian Academic Press, pp. 127-150.

HOFFMAN, E. (1989) Lost in translation. London: Vintage.

HYNDMAN, J. (2010) 'Introduction: the Feminist Politics of Refugee Migration'. Gender, Place \& Culture: A Journal of Feminist Geography 17(4): 453-459.

HYNDMAN, J. and GILES, W. (2011) 'Waiting for what? The Feminization of Asylum in Protracted Situations. Gender, Place \& Culture: A Journal of Feminist Geography 18(3): 361-379.

KLEIN, S. (2006) Time: a User's Guide: Making Sense of Life's Scarcest Commodity. London: Penguin Books.

KOSER, K. (2016) 'Introduction' Unaccompanied Minors Virtual Issue. Journal of Refugee Studies.

KUUSISTO-ARPONEN, A. (2016) 'Perheettömiksi suojellut: yksin tulleiden alaikäisten oikeus perheeseen'. In Fingeroos, O., Tapaninen, A. and Tiilikainen, M. (eds.) Perheenyhdistäminen. Kuka saa perheen Suomeen, kuka ei ja miksi? Tampere, Finland: Vastapaino, pp. 89-110.

LARRUINA, R. and GHORASHI, H. (2016) 'The Normality and Materiality of the Dominant Discourse: Voluntary Work Inside a Dutch Asylum Seeker Center'. Journal of Immigrant \& Refugee Studies 14(2): 220-237.

LEVINE, R. (1997) A Geography of Time. New York: Basic Books.

LEWIS, C.S. (1978) A Grief Observed. London: Faber and Faber.

MANN, G. (2004) Separated Children: Care and Support in Context. In Boyden, J. and De Berry, J. (eds.) Children and Youth on the Front Line: ethnography, armed conflict and displacement. New York: Berghahn Books, pp. 3-22.

MCEVOY-LEVY, S. (2014) 'Stuck in Circulation: Children, 'Waithood' and the Conflict Narratives of Israelis and Palestinians'. Children's Geographies 12(3): 312-326.

MOUNTZ, A. (2011) 'Where Asylum-Seekers Wait: Feminist Counter-Topographies of Sites Between States. Gender, Place \& Culture: A Journal of Feminist Geography 18(3): 381-399.

NÍ RAGHALLAIGH, M. (2013) 'The Causes of Mistrust amongst Asylum Seekers and Refugees: Insights from Research with Unaccompanied Asylum-Seeking Minors Living in the Republic of Ireland'. Journal of Refugee Studies 27(1): 1-19.

QVONTRUP, J. (2004) 'Editorial: The Waiting Child'. Childhood 11(3): 267-273.

ROTTER, R. (2016) 'Waiting in the Asylum Determination Process: Just an Empty Interlude?' Time \& Society 25(1): 80-101. 
SCHWEIZER, H. (2008) On Waiting (Thinking in Action). London: Routledge.

SIRRIYEH, A. (2013) Inhabiting Borders, Routes home: Youth, Gender, Asylum. Farnham, UK: Ashgate.

SOURANDER, A. (1998) 'Behavior Problems and Traumatic Events of Unaccompanied Refugee Minors. Child Abuse \& Neglect 22(7): 719-727.

UNITED NATIONS HIGH COMMISSIONER FOR REFUGEES [UNHCR], (2016) UNHCR review of gender equality in operations. Geneve, Switzerland: UNHCR.

UZUREAU, O. and SENOVILLA HERNÁNDEZ, D. (2016) 'Unaccompanied Migrants' Inactivity in France'. Fieldwork note. Young migrants' coping strategies to face inactivity periods in France. Available at <https://omm.hypotheses.org/955> (accessed 20/11/2016).

VERVLIET, M. (2013) The Trajectories of Unaccompanied Minors: Aspirations, Agency and Psychosocial Wellbeing. Ghent, Belgium: Academia Press.

VERVLIET, M., VANOBBERGEN, B., BROEKAERT, E. and DERLUYN, I. (2015a) 'The Aspirations of Afghan Unaccompanied Refugee Minors before Departure and on Arrival in the Host Country. Childhood 22(3): 330-345.

VERVLIET, M., ROUSSEAU, C., BROEKAERT, E. and DERLUYN, I. (2015b)

'Multilayered Ethics in Research Involving Unaccompanied Refugee Minors'. Journal of Refugee Studies 28(4): 468-485.

VITUS, K. (2010) 'Waiting Time. The De-subjectification of Children in Danish Asylum Centres. Childhood 17(1): 26-42.

WADE, J., SIRRIYEH, A., KOHLI, R. and SIMMONDS, J. (2012). Fostering unaccompanied Asylum-Seeking Young People: Creating a Family Life across a "World of Difference". London: British Association for Adoption and Fostering.

WESTLAKE, D., and JONES R.K. (2017) Breaking Down Language Barriers: A PracticeNear Study of Social Work Using Interpreters, The British Journal of Social Work, bcx073, https://doi.org/10.1093/bjsw/bcx073 